2016

\title{
Muslim-Paulician Encounters and Early Islamic Anti-Christian Polemical Writings
}

Abed el-Rahman Tayyara

Cleveland State University, abedtayyara@gmail.com

Follow this and additional works at: https://engagedscholarship.csuohio.edu/clmlang_facpub

Part of the Islamic Studies Commons

How does access to this work benefit you? Let us know!

\section{Publisher's Statement}

This is an Author's Accepted Manuscript of an article published in Islam and Christian-Muslim Relations 2016, available online: http://www.tandfonline.com/10.1080/ 09596410.2016 .1218650 .

\section{Recommended Citation}

Tayyara, Abed el-Rahman, "Muslim-Paulician Encounters and Early Islamic Anti-Christian Polemical Writings" (2016). World Languages, Literatures, and Cultures Faculty Publications. 137.

https://engagedscholarship.csuohio.edu/clmlang_facpub/137

This Article is brought to you for free and open access by the Department of World Languages, Literatures, and Cultures at EngagedScholarship@CSU. It has been accepted for inclusion in World Languages, Literatures, and Cultures Faculty Publications by an authorized administrator of EngagedScholarship@CSU. For more information, please contact library.es@csuohio.edu. 


\title{
Muslim-Paulician Encounters and Early Islamic Anti-Christian Polemical Writings
}

\author{
Abed el-Rahman Tayyara \\ Department of World Languages, Literatures and Cultures, Cleveland State University, \\ Cleveland, $\mathrm{OH}, \mathrm{USA}$
}

\begin{abstract}
This article investigates the portrayals of the Paulicians in early Islamic sources and specifically analyses the role that Paulician religious views play in Islamic anti-Christian writings. The study also gives insights into the nature of materials that were available to Muslim scholars and the strategies they applied in constructing coherent arguments to refute certain Christian religious beliefs. In doing so, the study touches upon Muslims' religious needs and scholarly curiosity, which sheds light on their intellectual interactions with non-Islamic religious beliefs and philosophical ideas. The article demonstrates that references to Paulician religious beliefs can be found primarily in early Christian-Islamic polemics. Muslim polemicists, most of whom were Mu'tazilites, attempted to demonstrate the soundness and the coherence of Islamic tenets vis-à-vis inadequacies and contradictions in Christian doctrines. The reliance of Muslim polemicists on heresiographical discourse therefore constituted an important strategy to substantiate their polemical arguments. Two major issues stand out in Islamic portrayals of Paulician doctrines: the centrality of Paul of Samosata in the history of the sect, and his association with the view that Jesus was a human being devoid of divinity.
\end{abstract}

During Late Antiquity, the eastern fringes of the Byzantine Empire constituted fertile ground for the cross pollination of religious and intellectual ideas, among which dualist doctrines were well known. Such is the case of Gnosticism and Manichaeism, which continued to play a notable role in the region even after the advent of Islam (O'Grady 1995, 26-72; Reeves 2010, 7-20). These dualist beliefs found their way into certain Christian heretical sects that challenged the authority of the Orthodox Church. Among these Christian movements were the Paulicians, who flourished as both a religious and a military group in eastern Anatolia and Armenia between the sixth and twelfth centuries. The Orthodox Church regarded the Paulicians as heretics, linking them with religious schism and dualist doctrines such as Manichaeism and Marcionism. Little is known, relatively speaking, about the Paulicians' origin and doctrines due, as we shall see, to the problematic nature of the body of materials available on this movement.

The interest of modern scholars in Paulicians can be traced back to the seventeenth century as an offshoot of scholarly preoccupation with dualist and Gnostic movements, 
particularly Manichaeism. Two major themes figure prominently in these studies, the first of which is interest in tracing the origin of Paulician doctrines and their transmission to Western Europe (Garsoïan 1967, 16-25), and the second, the history of the Paulicians and their relations with Byzantium and the Orthodox Church (Vasiliev 1935, 232-241; Garsoïan 1967, 151; Lemerle 1973, 1-144; Ludwig 1998, 23-24; Runciman 1999, $27-$ 62). References to Islamic-Paulician encounters in modern scholarship amount to general and brief allusions that appear on the sidelines of studies on dualist movements or Armenian history. An emphasis is placed in these studies on the military and political cooperation between Muslims and Paulicians against the Byzantines (Dadoyan 1997, 3653; Tobias 2007, 95-114). These studies, therefore, lack a structured examination of Paulician religious views and the extent to which they influenced early Islamic-Christian polemics.

This article examines the portrayals of the Paulicians in early Islamic sources and explores the role that their religious beliefs played in Islamic anti-Christian polemical writings. It also analyses how Muslim polemicists employed Paulician religious beliefs in their arguments. In doing so, this essay offers insights into both the nature of materials that were available to Muslim scholars regarding Christian religious controversies, and the strategies they used to create effective arguments against their Christian adversaries. Exploring these themes also sheds some light on the cross-cultural transmission of knowledge and, specifically, the extent to which Islamic constructions of Paulician doctrines differ from their representation in Christian sources. To better understand the image of the Paulicians in Islamic accounts, it is necessary first to familiarize ourselves with the main sources of Paulician history and doctrines.

\section{The nature of the sources}

Most of our information on the Paulicians derives primarily from Greek and Armenian sources that can be characterized (particularly the Greek ones) as hostile (Garsoïan 1967, 27-79, 80-111; Lemerle 1973, 1-22; Hamilton and Hamilton 1998, 5-10). Besides the Armenian source known as the Key of Truth, which is considered the only source written by the Paulicians, all other materials on their history and doctrines have come to us through their opponents. There are two major reasons for the absence of original sources written by the Paulicians. First, the movement achieved only a short period of political independence in Tefrike during the ninth century. Second, the Byzantines, who emerged victorious in the military confrontation with the Paulicians in 872, and the Orthodox Church, seem to have been responsible for controlling the channels of information on the Paulicians. We ought therefore to be cautious in dealing with the available sources on the sect, bearing in mind possibilities of rhetorical and ideological construction used by Christian heresiographers.

The nature of the sources (particularly the Greek ones) thus poses a great challenge to scholars in their attempt to recover historical information from these materials. Furthermore, a comparison between the Armenian and Greek sources regarding the reconstruction of Paulician history and religious beliefs yields in certain cases contradictory pieces of information (Garsoïan 1967, 112). Hence, a further discussion of the sources is in order. Beginning with the Greek sources, our first treatise on Paulicians 
is ascribed to Peter of Sicily, whom the Byzantine authorities sent in 869 to Tefrike, the Paulician stronghold, to negotiate the release of prisoners (Garsoïan 1967, 55; Hamilton and Hamilton 1998, 65-66). His account, which reflected the stance of the Orthodox Church, influenced later Greek sources, such as those of the Patriarch of Constantinople Photius (d. 893), and other Greek chroniclers (Hamilton and Hamilton 1998, 5-14). References to the Paulicians in Byzantine Greek sources are therefore usually found in the contexts of heresiography and religious controversy. The association of the Paulicians with the bishop of Antioch, Paul of Samosata (d. 275), in some Christian accounts is a good example of their classification as a heresy affiliated with earlier sects.

The Armenian sources differ from the Greek in two major aspects: chronological scope and motivation. The Armenian portrayals of Paulician history cover a longer span than the Greek sources, but these references are limited to events that fall under earlier or later stages of the heyday of Paulician political history. Such is the case with reports on this sect that can be traced to the sixth century, whereas the Key of Truth, which is seemingly the only source written by the Paulicians, was discovered in the eighteenth century (Conybeare 1898, v-xi; Garsoïan 1967, 151-153). Yet, the history of the Paulicians during the ninth century, which is considered the peak of this movement, is almost absent from the Armenian sources. With regard to motives, Armenian chroniclers' primary concerns were to preserve the historical evolution of the Armenian Church in all of its religious aspects. According to Garsoïan (1967, 80-85), the Armenian materials therefore seem in certain cases to offer more authentic accounts about the Paulicians than the Greek sources.

Islamic representations of the Paulicians, which can be characterized as concise and fragmentary in nature, reflect two major themes: history of Islamic-Paulician relations, and their religious teachings. With regard to the first theme, Muslim writers focused on the military cooperation between these two sides against Byzantium during the ninth century. This was the zenith of Paulician influence, when they became an independent political entity under Islamic protection with their capital in Tefrike (Dadoyan 2011, 81106). As for Paulician doctrines, early Islamic anti-Christian polemical writings constitute an important source of information about this sect. Since this article primarily examines the way Muslim polemicists introduced Paulician religious ideas into their anti-Christian polemical writing, it is necessary now to familiarize ourselves with Paulician doctrines.

\section{The religious beliefs of the Paulicians}

The examination of Paulician doctrines is fraught with certain difficulties as a result of the biased and contradictory nature of the sources. This is evident, for example, in the question of the origin of this sect. Most sources associated the Paulicians with the bishop of Antioch, Paul of Samosata (Garsoïan 1967, 210-212; Hamilton and Hamilton 1998, 93). ${ }^{1}$ Christian Greek sources attributed to Paul Adoptionist views, ${ }^{2}$ according to which Jesus was born as a man and at a later stage of his life was adopted by God as His Son as a reward for his sinless and virtuous life (Garsoïan 1967, 211; Chadwick 2001, 166-170). Some writers associated the Paulicians with the Apostle Paul (Conybeare 1898, cxxix; Runciman 1999, 49), whereas others believed that they were the followers of a certain Paul who was the son of a Manichaean woman named Kallinike 
(Dadoyan 1997, 38-40; Runciman 1999, 48). Yet other sources affiliated the Paulicians with an Armenian named Constantine, who lived during the reign of the Emperor Constans II (r. 641-668) (Lemerle 1973, 52; Barnard 1974, 105).

With regard to Paulician religious beliefs, Orthodox Christian writers associated them mostly with dualistic doctrines, such as Manichaeism and Marcionism (Garsoïan 1967, 200-205; Loos 1974, 34-36; Nersoyan 1996, 99; Hamilton and Hamilton 1998, 70, 93). For example, Peter of Sicily related that Paulicians believed in 'two principles, an evil one and a good one; one who is the maker of this world and has power over it, the other has power over the world to come' (Hamilton and Hamilton 1998, 72). ${ }^{3}$ Regarding Mary, he added that Paulicians held that 'the Lord was not born of her, but brought His body from heaven, and that after the birth of the Lord she had other children from Joseph' (72). Paulicians also refused to accept the Eucharist and did not venerate the cross (72-73). From Peter's account, we also learn that Paulicians were selective in accepting certain Christian religious sources. They accepted the four Gospels with an emphasis on that of Luke, and the epistles of the Apostles (excepting Peter), but they rejected the Old Testament (73-74).

The Armenian source, Key of Truth, which was written by the Paulicians, echoed some views found in Greek sources about Paulician doctrines, but added more information. First, we learn that Jesus was created and not born as the Son of God: 'We confess and believe that there is one true God, of whom our Lord Christ speaketh ... Again we confess and believe in Jesus Christ, [a new creature and not] creator' (Conybeare 1898, 93-94). When it comes to the Father-Son relationship, Paulician views can be characterized, according to the Key of Truth, as Adoptionist. Specifically, they believed that Jesus became the Son of God only after he successfully passed through various stages of maturity and experiences, the first of which was baptism. Hence, baptism is a crucial component and, in Paulician religious teachings, should take place at a later stage in life (Conybeare 1898, 76-77, 86-87). With the completion of all these stages, Jesus:

was invited by the Spirit of God to converse with the heavenly Father; yea, then also he was ordained king of being in heaven and on and under the earth ... all this in due order the Father gave his only born Son. (75)

This Adoptionist view was confirmed by the Armenian writer, Gregory Magistros (d. 1058), who also associated the Paulicians with Paul of Samosata (Garsoian 1967, 212). Like the Greek sources, the Key assigned a minor role to the Virgin Mary in Paulician doctrines. Specifically, they believed that 'the holy evangelists and the sanctified apostles, yea, and our Lord Jesus Christ, declare Mary, prior to the birth, to be a virgin, but after the birth call her a wife and utterly deny her virginity ... ' (Conybeare 1898, 113). There is no mention in the Key of the veneration of the cross. With regard to sacraments, Paulicians believed in three: repentance, baptism, and Jesus' holy blood and flesh (87, 123). It is worth noting that Paulicians' belief in the Eucharist as stated here contradicts what Peter of Sicily says in this regard.

We have so far familiarized ourselves with the Paulicians in terms of sources, origin, and doctrines. The examination of the Greek and Armenian sources indicates that Paulician doctrines represent a departure from Orthodox Christian beliefs on two major points: the divinity of Christ and the status of Mary. The remainder of this article will 
examine the manner in which Islamic sources portray the Paulicians, and the extent to which their religious teachings influenced Islamic anti-Christian writings.

Early references to Paulician history in Islamic sources

Islamic portrayals of Paulician history and religious beliefs appeared primarily in three major genres: Christian-Islamic polemics, heresiography, and geographical-historical accounts. However, the bulk of early Islamic references to Paulician religious beliefs can be found in Christian-Islamic polemics. When it comes to the term 'Paulicians', there are two major forms of the name. Muslim scholars used the collective name Bayāliqa or Baylaqān̄̄ when they were depicting the Paulicians as a political and military group (Mas'ūdī 1965-al, 122; Qudāma 1967, 254). However, Muslim writers applied the feminine forms al-Fūliyya, al-Būlīqāniyya, or al-Būliyya when they referred to Paulician religious beliefs (Ibn al-Bitṛ īq 1905, 114; Jāḥiz 1991-al, 320-321; Shahrastān̄̄ 1992-al, vol. 2, 248; Ibn al-Nadīm 1996, 528; Warrāq 2002-al, 276; Maqdisī n.d.-al, vol. 4, 42). It is worth noting that the use of feminine collective nouns is usually indicative of sects or heresies, particularly in Islamic heresiographies. These different forms of the name 'Paulicians' are the nearest possible rendering of the Greek word Paulikianoi, where the letter ' $p$ ' in Greek is replaced in Arabic by ' $b$ ' or ' $\mathrm{f}$ ', according to Abū 'Isā al-Warrāq (d. 861) (Warrāq 1992-al, 70-72; Dadoyan 1997, 37). The lack of consensus among Muslim scholars over the term 'Paulicians' is indicative of the different channels of information that Muslim scholars used to reconstruct their representations of this sect.

Early Islamic narratives of Paulician political history underlined the military cooperation between the two sides against Byzantium during the ninth century. During this period, the Paulicians constituted a serious military concern for the Byzantines after they established a state with the city of Tefrike (Ibrīq) as its capital under Islamic protection (Ṭabarī 1960-al, vol. 9, 207, 218; Qudāma 1967, 254; Mas 'ūdī 1965al, 122 123). Al-Tabarī and al-Mas 'ūdī refer to the names of prominent Paulician and Muslim leaders who played a major role in the joint military struggle against the Byzantines. They also deem the year 863 to be the end of the Paulician state. Qudāma adds that the Paulicians lived on the northern borderline of Islamic fortresses and ascribes the demise and fall of the Paulician state to negligence on the part of the Islamic authorities. He says that, once the Paulicians left, Armenians came to settle in the region. Alluding to Paulician religious views, Qudāma reports that they held different opinions from the Byzantines on many religious issues, but he does not specify what these distinctions were.

\section{Paulician beliefs and early Christian-Islamic polemics}

Christian apologists who lived under Islam were the first to initiate anti-Islamic religious writings during the eighth century as a response to the qur'anic representations of Christian doctrines (Thomas 2002, 14-20). Refuting Christian beliefs in the Trinity, the divine nature of Jesus, and the crucifixion was central to these qur'anic portrayals, as can be seen, for example, in Q 3.55; 4.157-158, 171, and 9.30-31 (see Reynolds 2009, 238245; 2014, 51-53). ${ }^{4}$ Early Christian anti-Islamic polemical works, which were written in Greek and Syriac (Penn 2015, 53-74), revolved around two major themes: the depiction of Islam as a Christian heresy or pagan cult, and the characterization of Muhammad as a 
false prophet. ${ }^{5}$ This orientation is clearly exemplified in the writings of the Melkite theologian John of Damascus (d. 750), who served in the Islamic administration under the Umayyads (Le Coz 1992, 41-58; Griffith 2001, 19-22). John of Damascus intended both to refute Muslims' claims against Christian doctrines and to provide his coreligionists with clear instructions on how to reply to Islamic criticism (Sahas 1972, 70-78; Le Coz 1992, 75-80; Tolan 2002, 50-55; Griffith 2008, 32-44). For example, he used Q 4.3 to show inconstancies in Islamic legislation concerning marriage and divorce and Q 5.114 to demonstrate Islamic misunderstanding of the importance of the Last Supper (Sahas 1972, 90-93).

The earliest Islamic polemical writings against Christianity seem to have been composed at the beginning of the ninth century. By that time, not only had Muslim scholars acquired extensive knowledge of Christian theology and sectarianism, but they were also enhancing their argumentation by applying techniques of logic borrowed from Greek philosophy (Zaman 1997, 49-58; Gutas 1998, 53-60). The incorporation of Greek philosophy into Islamic speculative discourse ( $\mathrm{ilm}$ al-kalām) is primarily associated with Mu'tazilite Muslim scholars (Monnot 1983; Reynolds 2004, 28-31; van Ess 2006, 97$116 ; 1975)$. No wonder, therefore, that most of these early Muslim polemicists were actually $\mathrm{Mu}$ 'tazilite scholars. Among these intellectuals were Bishr b. al-Mu'tamir (d. 825) (van Ess 1991-1997, vol. 3, 109, 139-142), Abū al-Hudhayl al-'Allāf (d. 841) (van Ess 1991-1997, vol. 3, 220), and Abū Isḥāq Ibrāhīm al-Naẓāām (d. 840) (van Ess 19911997, vol. 3, 296-298; Reynolds 2004, 28-34). Unfortunately, most of their works are not extant except for fragments preserved in later $\mathrm{Mu}$ 'tazilite works, such as those of Abū 'İsā al-Warrāq (d. 861) (Thomas 2006, 267-274; 1996), al-Jāḥiz (d. 869), and al-Qāọ̄ 'Abd al-Jabbār al-Asadabādī (d. 1025).

Early Islamic polemical writings focused on four major Christian religious themes: the Trinity, the Incarnation, the divine qualities of Jesus, and the crucifixion. Muslim polemicists characterized Jesus as a prophet and a human being, devoid of any divine qualities (Q 4.59; 5.73-75, 116; 19.35), and asserted that he was not crucified (Q 4.157; Swanson 2006, 248-256; Reynolds 2009). To that end, Muslim scholars attempted to demonstrate the soundness and coherence of Islamic tenets while pointing to inadequacies and contradictions in Christian doctrines (Rassī 2000-al, 17-58). This Islamic perception is informed by the belief that Christians had altered the primordial divine message that began with Adam and was restored and concluded with Muhammad's prophethood.

Three main Christian groups figured prominently in Islamic anti-Christian writings: the so-called Nestorians, Jacobites, and Melkites ${ }^{6}$ (Shahrastānī 1992-al, vol. 2, 247- 256; Asadabādī 2010-al, xxi-xxx, 1-2, 9-13; 1958-al, 80-85, 146-151; Khawārizmī n.d.-al, 35). Muslim polemicists resorted to two major strategies to illustrate contradictions and inconsistencies in Christian beliefs, the first of which was to convey disagreements between these three groups. Second, to further substantiate their arguments, they incorporated religious ideas of Christian sects labelled as heresies by mainstream Christianity. This is evident, for example, in Islamic references to Arianism, ${ }^{7}$ Macedonians, ${ }^{8}$ and the Paulicians, who are the main subject of this study. ${ }^{9}$ However, Muslim scholars knew much less about Paulician doctrines than those of other Christian heresies. This shortage of knowledge about Paulician religious beliefs is indicative of the manner in which information about this sect emerged in the Christian sources. Allusions 
to the Paulicians appeared in Christian heresiographies only at a later stage, when materials about other heresies were already in circulation. These narratives seem to have been the reports that Muslim polemists consulted to reconstruct their representations of the Paulicians. The treatments of the teachings of Paul of Samosata in Christian sources are a good example of this orientation. The examination of Islamic representations of the Paulicians points to three principal themes: the divinity of Jesus, the relationship between God and Jesus, and the status of Mary.

\section{The divinity of Jesus}

The divinity of Christ with its overriding theme of salvation constitutes the bedrock of Christian theology. However, the nature of this divinity (particularly the relationship of God the Father to the Son) yielded many intra-Christian debates during the formative stages of Christian theology (see Gallagher 2008). No other issue demarcated such an unequivocal religious distinction between Islam and Christianity. Muslims believe that God created Jesus in the womb of Mary without a father, but as a mere human devoid of any forms of divinity (Q 5.116; 19.19, 30). Nevertheless, Jesus' significant status in Islam derives from his being chosen by God, like other prophets, to guide humans to His path and divine message (Räisänen 1980; Khalidi 2001, 9-17; 2003, 23-30). Muslim polemicists argued that the divinity of Jesus showed the irrationality of Christian beliefs, as a monotheistic religion, and the contradictory nature of their scriptures. No wonder, therefore, that the divinity of Jesus occupies a prominent place in early Christian-Islamic polemical writings. To further substantiate their reasoning, Muslim polemicists drew, as we shall see, on religious beliefs espoused by Christian heretical groups, such as the Paulicians.

The first recorded reference to Paulician doctrines seems to be in Abū 'Īsā al-Warrāq's treatise entitled Kitāb al-radd 'alā al-thalāth firaq min al-Nasạ̄ rā (Book of the Refutation of the Three Christian Sects). This work is primarily preserved in the response of the Jacobite theologian Yahyā b. 'Adī (d. 974), ${ }^{10}$ who disputed over two main theological issues: the Trinity and the Incarnation (Ibn 'Adī 1987, 209; Thomas 2002, 60-66; Warrāq 2002-al, 71). Al-Warrāq's first allusion to the Paulicians is in his discussion of the Jacobites' view regarding the Incarnation (al-ittihād), which he defines as the two substances (uqnūm; pl. aqānīm) of Jesus (the divine and the human) becoming one hypostasis. Al-Warrāq also refers here to Paul of Samosata, whom he presents as the founder of the Paulician movement. He adds that, unlike the Jacobites, Paul of Samosata as well as his followers (ashāab būlī), Arius (d. 336), and Muslims believed that Jesus is not divine but rather that he is, like other prophets, God's human servant (insān 'abd) (Ibn 'Adī 1987, 174; Warrāq 2002-al, 194, 236). Elsewhere, al-Warrāq reiterates this view, reporting that Arius, Paul of Samosata, and Muslims concur that Jesus was created (makhlūq) and temporal (muhdath) (Ibn 'Adī 1987, 174; Warrāq 2002-al, 244).

Al-Warrāq's use of these terms echoes to a certain extent accusations brought against Paul of Samosata by the Orthodox Church, specifically his denial of the preexistence of Christ and his promotion of Adoptionist views, which include the two following ideas: first, that, since Christ only derived his divinity from the Father, he was a lesser god; and, 
second, that the Word of God and Christ are of different substances (Behr 2001, 207-235; Chadwick 2001, 166-169). Interestingly, almost the same charges of deviation that the Orthodox Church pressed against Paul of Samosata were associated with other heretical leaders, such as Arius and Nestorius (d. 450), whose names reverberate in tandem in Islamic sources (Galvão-Sobrinho 2013, 32-33, 26-46). Al-Warrāq's presentation of Paul's views regarding Jesus' divinity in conjunction with the Paulicians and Arius thus illustrates how Muslim scholars drew on their perceptions of intra-Christian debates and the heresiological discourse around such figures as Paul of Samosata and Arius.

A reference to Paul of Samosata and his followers, the Paulicians, can be found in alMas 'ūdī's (d. 956) Tanbīh under his treatment of the differences between Melkites, Nestorians, and Jacobites concerning the human and the divine natures of Jesus. Describing the historical background that led to the fourth Ecumenical Council of Chalcedon in 451, al-Mas 'ūdī relates that:

Paul of Samosata (al-Shimshati) who was the first patriarch of Antioch instituted this [Paulician] sect. The holders of the Sees [among the Paulicians], who venerated other luminaries and worshiped them according to their ranks, were mediating between Christian beliefs, Zoroastrianism (al-majūsiyya), and dualism. (Mas' ūdī 1894-al, 151)

From this short passage one learns that Paul of Samosata, who served as the patriarch of Antioch, was the founder of the Paulician sect. Mas 'ùdī (1894-al, 151) describes their doctrines as an astral religion that synthesizes different elements derived from Sabian philosophy, ${ }^{11}$ Christian beliefs, Zoroastrianism, and dualism. The affiliation of the Paulicians with Zoroastrianism and Sabian philosophy here is indicative of their geographical location and the accessibility of various religious doctrines and philosophical ideas that were predominant in the east. At the same time, al-Mas 'ūdī's presentation demonstrates how some Muslim scholars placed their discussion of Paulician views more within a historical-philosophical framework than in the religious arena. This may explain the absence of an explicit reference to Jesus' human or divine nature. This orientation is also evident in al-Maqdisī's (d. after 970) Bad' wa-al-ta' rīkh (Beginning and History). From his account, we learn that the Paulicians lived in an area of $\mathrm{H}$ arrān ${ }^{12}$ and their religious teachings were influenced by dualist doctrines and Aristotelian philosophy (Maqdisī n.d.-al, vol. 4, 42).

A more explicit argument against the divinity of Jesus is found in the heresiographical work of the Andalusian scholar Ibn H azm (d. 1064), entitled Kitāb al-fasl f̣̂̄ al-milal waalahwā' wa-al-nihal (Book of the Clear Distinction between Sects, Capricious Views, and Heresies). His main objective in writing this work was to show inconsistencies and errors in religions and sects other than his strict literalist $Z$ āhirī interpretation of Islam (Behloul 2002, 122-130). Levelling harsh criticism on Christianity, Ibn H azm offered a detailed examination of the four Gospels, aiming to show contradictions and discrepancies in Christian religious beliefs (Ibn Hazm n.d., vol. 2, 2-7, 59-70). Referring to the Paulicians, Ibn Hazm relates that Paulicians, like other Christian groups, believed in the four Gospels (vol. 2, 2). Discussing the divinity of Jesus, Ibn Hazm, like al-Warrāq and al-Mas' $\bar{u} \bar{d} \overline{1}$, associates Paulician religious beliefs with those of Paul of Samosata. However, he provides a more explicit Islamic argument than previous Muslim scholars, stating that: 
Among [these sects] were the followers of Paul of Samosata (ashāāb Būlus al-Shamshātị ) who was a patriarch in Antioch before Christianity came to be the dominant religion (qabla zuh ūr al-Nasr āniyya). He [Paul] believed in absolute and pure monotheism (al-tawhīd almujarrad al-sahịh haintaining that Jesus ('Isā), like other prophets (May peace be upon them) is God's servant and messenger ('abd Allāh wa-rasūluhu). Although God, the Almighty, created him in Mary's womb without a man, he is a human being devoid of any forms of divinity (insān la ilāhiya fìhi). He [Paul] therefore, used to say 'I do not know what the Word (kalima) and the

Holy Ghost (al-rūḥ al-qudus) are purported to denote. (Ibn Ḥ azm n.d., vol. 1, 48)

In this passage Ibn $\mathrm{H}$ azm clearly voices the Islamic belief that Jesus is a prophet with no divine attributes. To substantiate this Islamic viewpoint, he applies his interpretation of Paulician religious views as a rhetorical device to demonstrate Jesus' unambiguous humanity. Specifically, Ibn Hazm ascribes the phrases al-tawhīed al-mujarrad al-sahīh (absolute and pure monotheism) and insān la ilāhiya fîhi (a human being devoid of any form of divinity) to Paul of Samosata, the founder of the Paulicians. He also associates with Paul of Samosata the view that Jesus' highly esteemed status and his special relation with God derived, as in the case of other prophets, from being His servant and a bearer of the same divine message. The last sentence of this quotation has a twofold objective: to confirm the qur'anic narrative of Jesus' humanity (Q 4.171; 5.116; 19.19, 30), and to refute the Christian belief in the Trinity, which is the essential foundation of Christology (Behloul 2002, 115-116).

So far, we have seen that references to the Paulicians in Islamic accounts can be divided into two main literary types: religious-polemical (al-Warrāq and Ibn Hazm) and historicalphilosophical (al-Mas' ūdē and al-Maqdisī). The main objectives for Muslim scholars whose reports are classified under the first type were to confirm the Islamic view of Jesus' human nature and to refute Christian beliefs regarding Jesus' divinity, as well as the Trinity. No wonder Paul of Samosata occupied a central role in these reports. Religious-polemical accounts can thus be described as rhetorical in nature and reflecting misinterpretations of religious beliefs that Christian heresiographers ascribed to Paul of Samosata, such as Adoptionism.

With regard to the Islamic historical-philosophical accounts, Muslim scholars were interested in placing their narratives of the Paulicians within a larger history of Christianity. By doing so, they attempted to show how these doctrines were influenced by other religious or philosophical ideas, such as dualism and Greek philosophy. These Islamic portrayals of Paulician views raise the question of the possible sources that influenced Muslim writers. The first step in answering this question is to examine Arab Christian sources, which played a crucial role in the transmission of knowledge from GrecoRoman and Christian history (especially in Greek and Syriac) into Islam.

The Arab Christian (Melkite) historian-theologian Sa'īd Ibn al-Bitṛ īq (d. 923), who was also known by his Greek name Eutychius, offers in his universal history the following report about Paul of Samosata:

During the first year of Claudius Caesar's reign Paul was appointed as the bishop of Antioch and he stayed in this post for eight years ... He was given the name Paul of Samosata (alSimīsātị ), because he was from Samosata. He innovated (ibtada'a) the Paulician doctrine 
(madhhab al-būlīqāniyya), and, hence, the followers (tābi 'ūn) of his religious beliefs were named Paulicians (būlīqāniyyūn) ... . Paul of Samosata held the belief that our Lord Christ (sayyidunā al-masīh ） was a human created from the Godhead (lāhūt) with the same human nature as ours. He [Jesus] was first born as the son of Mary, but since he was chosen as the savior (mukhallis ) of the human race (al-jawhar al-insī), the divine nature (al-ni' ma alilāhiyya) was incarnated into him by [God's] Grace (almaḥabba) and Will (al-mashī'a); and for this reason he was called the Son of God (ibn Allāh). He [Paul] also claimed that God is of one unequalled nature and substance and he did not believe in the Word (al-kalima) or the Holy Spirit (al-rūḥ al-qudus). (Ibn al-Bit rīq 1905, 114)

Eutychius demonstrates here familiarity with both Christian sources and the complexities of intra-Christian theological debates. As a historian, he first situates the episode of Paul of Samosata within Roman history and, specifically, during the reign of Claudius II (r. 268-270). Eutychius opens with the phrase 'he innovated the Paulician doctrine (ibtada'a madhhab al-būlīqāniyya)' to label Paul's beliefs as a heresy diverging from mainstream Christianity. His account consists of three major accusations against Paul of Samosata. First, the denial of the preexistence of Christ and the belief in Adoptionism: namely, Jesus was born as a human and was only later chosen as the saviour of humanity when God granted him divine grace and adopted him as His Son. A reference to Paul of Samosata's views on Adoptionism are found in the universal history of Maḥūb b. Qunstant 1 n (d. 941), ${ }^{13}$ but he does not associate him with the Paulicians (Ibn Qunstant $\overline{1} \mathrm{n}$ 1911, 530). Ibn Qunstant 1 n's account gives the impression that the connection between Paul and the Paulicians might have been a rhetorical convention used by Christian heresiographers to label this group as a heresy. However, since the Key of Truth strongly affiliates Adoptionism with the Paulicians, one cannot exclude the possibility that this connection was an integral part of their beliefs (Conybeare 1898, 74-75, 80, 100, 108).

Second, Eutychius ascribed to Paul the belief that 'God is of one unequalled nature and substance', which indicates that Jesus enjoyed a certain level of divinity, but was not an equal or co-eternal with God. Finally, Eutychius' claim that Paul 'did not believe in the Word (al-kalima) or the Holy Spirit (al-rūh al-qudus)' suggests his rejection of the Trinity.

Eutychius' presentation of the religious views associated with Paul of Samosata and the Paulicians bears similarities to Islamic polemical accounts, such as that of Ibn $\mathrm{H}$ azm. However, there are some significant distinctions between Muslim scholars and Eutychius. What distinguish Eutychius' report from those of Muslim polemicists are primarily the interpretations and religious agenda. For example, Ibn $\mathrm{H}$ azm ascribes to Paul the belief in Jesus' human nature and the denial of Trinity seemingly because these ideas conformed to the Islamic view in this regard, but he does not refer to the Adoptionist concept that figured in Eutychius' account as well as in other Christian heresiographies. A clear reference to the notion of Adoptionism can be found in 'Abd al-Jabbār's Mughnī. He relates that a Christian sect believed that Jesus' (al-masīh) incarnation was from Mary and, because he was a pious prophet, God honoured and favoured him by calling him His son by adoption, but not by birth (Asadabādī 1958-al, 85, 105). The fact that he does not identify this view specifically with the Paulicians or Paul of Samosata gives the impression that Christian heresiographies were the main source used by Muslim polemicists. 
Eutychius' main objective here was to elucidate the intricacies of intra-Christian debates and clarify how Paul's views differed from mainstream Christian theology. Unlike Islamic accounts, Eutychius intended to show that Paul's religious views were heretical. The departure of this heresy from mainstream Christianity can be seen primarily in two major issues: the stage at which Jesus became divine, and the level of this divinity. Eutychius' account also sheds some light on the process of transmission of knowledge regarding intra-Christian debates and heretical views into the Islamic world.

The attempt to find Eutychius' possible Christian sources leads to a letter written in Syriac by Simeon of Beth Arsham (d. c. 548), whose writings against heresies were greatly influenced by earlier Greek sources (Becker 2006, 47-55). Simeon's reference to Paul of Samosata and his heretical views occurs in a discussion of the 'Nestorian' heresy, where his name appears among other major heretical leaders, such as Simeon Magus, Ebion, and Nestorius (Ibn Qunstant 1 n 1911, 322; Behr 2001, 137-144). Like Eutychius, Simeon claims that Paul denied the preexistence of Jesus' divinity, claiming that he was born as a human and only later became the son of God by grace (teb ūtā) (Simeon of Beth Arsham 2002, 347). However, unlike Eutychius, he does not mention Paul's rejection of the Trinity.

To sum up, Christian sources portray Paul of Samosata as an influential heretical leader whose views the Orthodox Church associated with previous heresies. Discussions of Paul's religious teachings in Christian sources revolve around the questions of when, and the extent to which, Jesus was divine, but not whether he was human or not. A comparison between the portrayal of the religious views of Paul of Samosata and the Paulicians in Islamic and Christian sources thus supports the conjecture that Muslim scholars availed themselves of the heresiographical discourse to substantiate their polemical argument in line with their own religious beliefs.

The concept of rahma and the God-Jesus relationship

According to Paulician religious views, which have reached us through Orthodox Greek sources, Jesus did not maintain a unique relationship with God as His Son. For example, Peter of Sicily ascribes to the Paulicians the belief that Jesus was an angel sent into the world by God, and that his real mother was heavenly Jerusalem (Hamilton and Hamilton 1998, 94). A clear reference to the Paulician belief in the human nature of Jesus is given in the Key of Truth, where Jesus appears under the epithet 'the newlycreated Adam' (Conybeare 1898, 79). Paulicians also believed, according to the Key, that 'Jesus ... [a new creature and not] creator, as St. Paul saith ... is faithful to the creator, as was Moses in all his house' (94). It is instructive now to examine the extent to which Paulicians' views of the non-unique God-Jesus influenced Muslim scholars.

Islamic sources stress the belief that Jesus is a human being who acquired his significant status from being a prophet sent by God, like other prophets, to communicate His divine message to humanity. At the same time, Jesus' birth constitutes, according to the qur'anic narrative, a distinctive case, as God created Jesus in the womb of Mary without a man (Q $5.116 ; 4.171 ; 19.19,30)$. The miraculous birth of Jesus thus seems to have posed a certain challenge for Muslim polemicists trying to refute the fundamental Christian belief in 
Jesus' divinity as God's Son. Muslim scholars therefore pursued three major strategies, the first of which was to question the authenticity of Christian scriptures by pointing to inconsistencies and contradictions. Specifically, Muslim scholars argued that, during the apostolic period, Christians distorted the teachings of the primordial divine message. Second, Muslim scholars attempted to demonstrate that the miraculous birth of Jesus, though distinctive, is not unique. Muslim polemicists sought to show that Jewish and Christian scriptures contain abundant examples of the figurative portrayal of God as the father of all humans, in the sense that He is their creator and loving Lord. This fatherly characterization of God was then applied mistakenly by Christians to His relationship with Jesus (Asadabādī 1958-al, 109-113; 2010-al, 39-40, 44-46; Nāshi' 1971-al, 82-83; Rassī 2000-al, 44-45; Ibn H azm n.d., vol. 2, 24, 32-36, 57-59, 64-69). ${ }^{14}$ Finally, Muslim polemicists drew on doctrines of certain Christian heresies to argue against the Christian belief in the divinity of Jesus as God's son. Such is the case with Islamic employment of Paulician doctrines, and particularly the refutation of Jesus' divinity, in the context of their discussions of the qur'anic concept of rahma (divine mercy). ${ }^{15}$

The earliest allusions to the qur'anic notion of rahma are found in the works of al-Rassī and al-Jāhiz, who discuss the term primarily at the lexical and etymological level (J āḥiz 1991-al, vol. 3, 341-342; Rassī 2000-al, 19-31). Unlike al-Rassī, al-Jāḥiz also places the term rahma within the story of Abraham to account for his distinct epithet khalīl alrahmān (Friend of the Merciful), which signifies his prophetic mission. The distinctive rapport between Abraham and God is, according to al-Jāhiz, analogous to that between God and other prophets, such as Jesus, who was awarded the title 'Spirit of God' (rūh allāh) for being a prophet born without a father. However, al-Jāhị does not refer to the Paulicians in his discussion.

The first clear connection between the term rahma and Paulician views concerning the Father-Son relationship was made by al-Maqdisī. He wrote,

Paulicians believed that God is absolute and His knowledge is co-eternal [preexistent] with Him, and that Jesus is His son in the sense of mercy the same way one can say that Abraham is the 'Friend of the Merciful (khalīl al-rahmān)'. (Maqdisī n.d.-al, vol. 4, 46)

This short report clearly shows how Islamic polemical writings employed the term rahma to offer a better explanation for the distinctive relation of Jesus as a prophet with God and to refute the belief in the divinity of Christ. Al-Maqdisi first acknowledges the distinctive connection between God and Jesus, who was born without a father. Like other Muslim scholars, he then emphasizes that this relationship, which derives entirely from Jesus' prophetic mission, is not unique. To that end, al-Maqdisī evokes the qur'anic story of Abraham, who was granted the epithet 'Friend of the Merciful', as another example of a God-prophet association. His reference to the Paulicians thus serves here as a further attestation to the use of doctrines of certain Christian heresies to argue against the Christian belief in the divinity of Jesus.

The parallelism between the special God-Jesus relationship and that of Abraham as His friend is further discussed in 'Abd al-Jabbār's Al-mughnī. He argues that Abraham's epithet 'Friend of the Merciful' (khalīl al-raḥmān) denotes choosing (isț if̣ $\bar{a}$ ') and distinction (ikhtisạ̄ s. . He adds that the title khalīl indicates that God singled out Abraham as a prophet and bestowed upon him special prophetic attributes, such as revelation (wahy) 
and grace (karāma). To substantiate this prophetic analogy, 'Abd al-Jabbār invokes the story of the creation of Adam as a perfect example of a prophet whom God created without a father or mother. Interestingly, this comparison between Adam and Jesus resonates with the epithet 'new-created Adam' that Paulicians gave, according to the Key of Truth, to Jesus (Conybeare 1898, 114). 'Abd al-Jabbār concludes his account by saying that the analogy of khalīl, which informs the God-Abraham relationship, can be applied to any prophet, including Jesus, with the exclusion of fatherly association (Asadabādī 1958-al, 106-107, 112-113).

What stands at the heart of the arguments made here by Muslim scholars is the understanding that the special relation of Jesus to God is, as in the case of other prophets, only that of a prophet. The attempt to pinpoint the extent to which they were influenced by Paulician doctrines is not an easy task. No doubt Muslim polemicists were primarily influenced by Orthodox heresiographical (Melkite or Jacobite) writings. At the same time, the similarity between Islamic portrayals of this non-exclusive God-Jesus relationship and that found in the Key of Truth presents the possibility that they were also influenced, perhaps to a lesser degree, by Paulician religious views. Whether this information reached Muslim scholars directly from the Key of Truth or from its earlier sources is, however, difficult to establish here.

\section{The status of Mary}

No other woman occupies a higher status in the Qur'an than the Virgin Mary (Maryam) because God chose her above all women for her purity and righteousness (Q 3.37-42; 66.12). Indeed, the nineteenth chapter of the Qur'an is called 'Maryam', after Mary. She figures prominently in the Qur'an and the Prophetic traditions regarding the miraculous birth of Jesus (Q 3.45-51; 19.16-26; 21.91; Wensinck 1991). This is the fundamental understanding that informs the high esteem that Mary enjoys in Islam. At the same time, Islamic traditions stress that Mary was only a human being without divine attributes.

The status of Mary and her role in the Incarnation was a subject of debate among Christian theologians in the first centuries of Christianity. In mainstream Christian theology, Mary is called the Virgin because she conceived Jesus miraculously by the Holy Spirit. Christian traditions differ on the way in which Christ was conceived by Mary, including ideas that it was through her mouth or eyes, though the belief that the conception occurred through her ear became the consensus during the fifth century because Jesus was God's Word (Constans 2003, 275-282). She was thus awarded the title 'God-bearer', theotokos, for her indispensable role in the Incarnation of Christ, the 'Saviour of humanity' (Thurlkill 2007, 12-14, 44-56).

From the available Greek and Armenian sources, it is hard to arrive at a conclusive synthesis regarding the role of Mary in Paulicians' religious views. For example, Peter of Sicily relates that the Paulicians believed that Mary 'gave birth to God in appearance and not in reality ... after the divine birth she had other sons with Joseph' (Garsoïan 1967, 157, 173, 211; Hamilton and Hamilton 1998, 69, 94, 100, 101). He also claims that, according to the Paulicians, Jesus was not born of Mary, but rather he brought his body from heaven and passed through Mary as through a pipe (Hamilton and Hamilton 1998, 72, 103 n. 4; Runciman 1999, 50). Theophylact Lecapenus (d. 956) relates that Paulicians 
believed that 'Jerusalem which is above' is Jesus' mother and not Mary (Hamilton and Hamilton 1998, 100). From the Armenian work, the Key of Truth, we learn that Mary played a minor role in the Jesus story and was presented as the bearer of the 'newcreated Adam'. She also did not remain a virgin after she gave birth to Jesus (Conybeare 1898, 114). From these accounts one can say that the Paulicians rejected any active participation by the Virgin Mary in the Incarnation.

The view that Mary played a passive role in the Incarnation, which Christian heresiographers ascribed to the Paulicians, found its way into some Islamic polemical works. Explaining the relationship between the Messiah and the Word (al-kalima), 'Abd alJabbār recounts that, according to an earlier Christian belief, the Word at the time of union passed through Mary's abdomen as an arrow flies through the air and as water runs through a pipe (mīzāb) (Asadabādī 1958-al, 85). But he does not identify this view explicitly with a specific sect. A similar portrayal of the birth of Jesus and the status of Mary is found in Ibn H azm's Fas! (Ibn H azm n.d., vol. 2, 35). ${ }^{17}$ Whether Muslim scholars received these perceptions about Mary directly from accounts ascribed to the Paulicians is hard to establish. However, it is more likely that these opinions about the secondary status of Mary found their way to Muslim polemicists through Orthodox heresiographies. This conjunction can be inferred from al-Shahrastānī (d. 1153) who relates:

A group from the Jacobites claimed that the Word (Logos) did not receive any flesh from

Mary, but it passed through her as water goes through a pipe. The human form (shakhs) of Christ (al-masīh), peace upon him, was merely imagination and similar to the reflection in the mirror. Therefore, he was not embodied nor having dense substance in reality ... Those [who accept these views] called al-Ilyāniyya [or al-Uluāniyya]. (Shahrastānī 1992-al, vol. 2, 255)

Al-Shahrastāni describes here the view that Jesus was not born of the Virgin Mary, but merely passed through her as through a pipe. He ascribes this opinion to a Jacobite sect named al-Ilyāniyya (or al-Uluāniyya). This account demonstrates that, like other Muslim polemicists, al-Shahrastānī relied on Christian heresiographies on the status of Mary. In doing so, he echoes the well-regarded status that Mary occupies in Islamic traditions as the mother of Jesus, with the exclusion of any divine attributes.

\section{Conclusion}

Besides being a military zone, the borderland that geographically separated the Islamic empire and Byzantium constituted a confluence of intellectual ideas and dualist beliefs. This religious syncretism founds its way into certain Christian sects that were labelled by the Orthodox Church as heresies; the Paulicians were one of these groups. Our knowledge about their doctrines drives primarily from Christian heresiogaphies. Religious views ascribed to the Paulicians, such as the divinity of Jesus, the God-Jesus relationship, and the status of Mary, played an important role in Islamic anti-Christian polemical writings. The analysis of Islamic narratives of Paulician history and doctrines thus provides a different angle from which to look at the process in which Christian heretical views reached Islamic sources (including Arab Christian traditions) and the way Muslim polemicists employed these ideas in their writings. 
Islamic representations of Paulician history and religious beliefs amount to brief references that reflect three major concerns: first, political/military interest, which reflected the joint military cooperation between these two sides against their common enemy, Byzantium; second, the religious/polemical concern, which constitutes the heart of this study and is reflective of Muslim scholars' search for effective argumentation strategies to apply to their anti-Christian polemics; and finally, a few references to the Paulicians can be characterized as demonstrating a historical/philosophical interest in this group.

Islamic polemical writings revolved primarily around refuting the Christian religious beliefs in the Trinity, the crucifixion, and the divinity of Jesus. Following the qur'anic teachings, Muslim polemicists emphasized the absolute oneness of God and the humanity of Jesus, whose special status derives, like that of other prophets, from his being a prophet. To enhance their argumentation strategies, Muslim scholars pointed out contradictions and inconsistencies in Christian doctrines. In addition, they incorporated religious views that the Orthodox Church ascribed to heretical sects, such as the Paulicians. Most of the information that Muslim polemicists had about the Paulicians consisted primarily of interpretations of accounts written by Christian heresiographers. Constant references to Paul of Samosata and his affiliation with the Paulicians constitute a good example of this orientation.

Christian sources portrayed Paul as a heretical figure for holding different beliefs about the status of Jesus (in relation to God) from those of Orthodox Christianity. Specifically, these differences revolved around the question of whether Jesus was preexistent and equal to God, but did not address beliefs about his humanity. However, Muslim polemicists presented Paul of Samosata as believing in the oneness of God and that Jesus was merely a human being devoid of divinity. The portrait of Paul of Samosata and the Paulicians delineated in Islamic sources is clearly consistent with Islamic religious teachings. This discrepancy between Islamic and Christian presentations of religious views ascribed to Paul and the Paulicians thus lends support to the assumption that Muslim scholars availed themselves of the heriosographical discourse to substantiate their polemical arguments. The same can be applied to Islamic incorporations of Paulician doctrines to refute Christian beliefs in the Father-Son relationship between God and Jesus, as well as the sanctification of Mary. However, one cannot entirely exclude the possibility that Muslim polemicists had access to other sources, particularly Armenian. This conjecture can be supported, for example, by the absence of Islamic references to the Paulicians' rejection of the veneration of images, the cross, and relics, which is in line with Islamic beliefs. Furthermore, examination of the sources and viewpoints also sheds some light on the question of representation and, particularly, the extent to which Islamic portrayals of Christian heresies signify different perspectives from those that dominated the GrecoRoman or Judeo-Christian milieus.

\section{Notes}

1. Peter the Higoumenos seems to have been the first Greek historian to associate the Paulicianswith Paul of Samosata. 
2. Adoptionism, which figured prominently in intra-Christian theological debates, refers to discussions of how the divine nature dwelled in the human. Although views on the moment of adoption might differ, baptism is commonly specified as the stage at which God adopted Jesus (Papandrea 2016, 23-43).

3. The same belief is described by Peter the Higoumenos (Hamilton and Hamilton 1998, 94).

4. In this article, Reynolds, analysing qur' anic references to the crucifixion and death of Jesus along with qur'anic exegesis, provides a thorough discussion of the topic arguing that, contrary to standard view on the subject, the Qur'an accepts Jesus' death.

5. For a good discussion of this subject on modern scholarship see Reynolds (2014).

6. Following the Ecumenical Councils of Ephesus in 431 and Chalcedon in 451, which were primarily convened to discuss the divine nature of Jesus, Christians at the advent of Islam were divided into three main groups: the Chalcedonians (Melkites), Jacobites (Monophysites), and Nestorians (Le Coz 1992, 24-28; Griffith 2001).

7. This sect was named after Arius (d. 336) who, following the first Council of Nicaea in 325 , was condemned as a heretic for believing that the Son was created and denying that he has the same substance as the Father (O'Grady 1995, 84-97; Kaatz 2012, 97-118).

8. This sect was founded by Macedonius (d. ca. 360), the bishop of Constantinople, who wasexcommunicated by the Orthodox Church for denying the divinity of the Holy Spirit (Chadwick 2001, 338, 421).

9. Interestingly, al-Jāhị refers to the Paulicians along with Manicheans, Daisaneans, and Marcionists as examples of sects that Christian philosophers, physicians, and astrologers brought to the Islamic intellectual milieu. As a result, some inexperienced Muslim scholars subscribed to these sects after they were lured by Christian scholars (Jāhiz 1991-al, 320 321).

10. Yahyā b. 'Adī, who was knowledgeable in Aristotelian philosophy (especially logic), represents in his theology a Monophysite view regarding the Incarnation of Jesus (Bonadeo 2011).

11. Sabians, who followed the Neo-Platonic school, worshiped seven planets as intermediariesbetween this world and heaven (Buck 1984; Tardieu 1986; Genequand 1999).

12. Under Islam, the city of $H$ arrān continued to be a centre of philosophical teachings of the Sabians, whose doctrine was a synthesis of Greek philosophy and Gnosticism.

13. Agapius was an Arab Christian Melkite scholar and the bishop of Manbij, which is located innorthern Syria (Graf 1944-1953, vol. 2, 34-35).

14. Besides the Lord's Prayer (Matthew 6.9), Muslim scholars draw mostly on John 14.28; 20.17; Matthew 5.16; 6.6; 13.43.

15. The term rahma, which appears more than 100 times in the Qur'an, carries a number of meanings, such as 'kindness', 'mercy', and 'benevolence', but, when it applies to God it denotes the favour (in 'ām) that He bestows upon His creatures. Hence, His divine name alRahimān (Gimaret 1994).

16. Wa-al-fūliyya qālū allāh wāḥid wa- 'ilmuhu qadīm ma'ahu wa-al-masīḥ ibnuhu 'alā wajh alraḥma, kamā yuqāl Ibrāhīm khalīl al-raḥmān.

17. It is worth mentioning that Nāshi' (1971-al, 81) ascribes this view to the Maronites. 


\section{References}

Asadabādī, 'Abd al-Jabbār al-. 1958. Al-Mughn̄̄ fī abwāb al-tawh īd wa-al-'adl. Edited by M. alKhuḍayrī. Vol. 5. Cairo: al-Dār al-Misriyya li-al-Tạ 'līf wa-al-Tarjama.

Asadabādī, 'Abd al-Jabbār al-. 2010. 'Abd al-Jabbār: Critique of Christian Origins (Tathbīt dalā'il alnubuwwa): A Parallel English Text. Edited and translated by G. S. Reynolds and S. K. Samir. Provo: Brigham Young University Press.

Barnard, L. 1974. The Graeco-Roman and Oriental Background of the Iconoclastic Controversy. Leiden: Brill.

Becker, A. 2006. Fear of God and the Beginning of Wisdom: The School of Nisibis and Christian Scholastic Culture in Late Antiquity Mesopotamia. Philadelphia: University of Pennsylvania Press.

Behloul, Samuel. 2002. Ibn Hazms Evangelienkritik: Eine methodische Untersuchung. Leiden: Brill.

Behr, J. 2001. The Way to Nicaea: The Formation of Christian Theology. Vol. 1. Crestwood, NY: St Vladimir's Seminary Press.

Bonadeo, C. M. 2011. "art. Yaḥyā b. 'Adī.” In Encyclopedia of Medieval Philosophy: Philosophy Between 500 and 1500, edited by H. Lagerlun, Vol. 2, 1421-1422. Dordrecht: Springer.

Buck, C. 1984. "The Identity of the Sabi 'un: An Historical Quest.” Muslim World 74: 172-186.

Chadwick, H. 2001. The Church in Ancient Society: From Galilee to Gregory the Great. Oxford: Oxford University Press.

Constans, N. 2003. Proclus of Constantinople and the Cult of Mary of the Virgin in Late Antiquity: Homilies1-5, Texts and Translations. Leiden: Brill.

Conybeare, F., ed. 1898. The Key of Truth: A Manual of the Paulician Church of Armenia. Oxford: The Clarendon Press.

Dadoyan, S. 1997. The Fatimid Armenians: Cultural and Political Interaction in the Near East. Leiden: Brill.

Dadoyan, S. 2011. The Armenians in Medieval Islamic History: Paradigms of Interaction, Seventh to Fourteenth Centuries, Vol. 1. The Arab Period in Arminnyah: Seventh to Eleventh Centuries. New Brunswick, NJ: Transaction.

van Ess, J. 1975. "The Beginnings of Islamic Theology." In The Cultural Context of Medieval Learning, edited by J. Murdoch, and E. Sylla, Vol. 26, 88-111. Boston, MA: D. Reidel.

van Ess, J. 1991-1997. Theologies und Gesellschaft im 2. und 3. Jahrhundert Hidschra: Eine Geschichte des Religiösen Denken im Frühen Islam. 6 vols. Berlin: de Gruyter.

van Ess, J. 2006. The Flowering of Islamic Theology. Translated from German by J. M. Todd. Cambridge, MA: Harvard University Press.

Gallagher, C. 2008. "The Episcopal Councils in the East." In The Oxford Handbook of Byzantine Studies, edited by E. Jeffreys, 583-591. Oxford: Oxford University Press.

Galvão-Sobrinho, C. R. 2013. Doctrine and Power: Theological Controversy and Christian Leadership in the Later Roman Empire. Berkeley: University of California Press.

Garsoïan, N. 1967. The Paulician Heresy: A Study of the Origin and the Development of Paulicianism in Armenia and the Eastern Provinces of the Byzantine Empire. The Hague: Mouton.

Genequand, Charles. 1999. "Idolâtrie, Astrolâtrie et Sabéisme.” Studia Islamica 89: 109-128.

Gimaret, D. 1994. “art. Rahma.” In Encyclopedia of Islam, Vol. 8, 398-399. Leiden: Brill.

Graf, G. 1944-1953. Geschichte der Christlichen Arabischen Literature. 5 vols. Citta del Vaticani: Biblioteca Apostolica Vaticana. 
Griffith, S. H. 2001. "Melkites, Jacobites, and the Christological Controversies in Arabic in the Third/Ninth-Century Syria." In Syrian Christians Under Islam: The First Thousand Years, edited by D. Thomas, 9-55. Leiden: Brill.

Griffith, S. H. 2008. The Church in the Shadow of the Mosque: Christians and Muslims in the World of Islam. Princeton, NJ: Princeton University Press.

Gutas, D. 1998. Greek Thought, Arabic Culture: The Graeco-Arabic Translation Movement in Baghdad and Early 'Abbasid Society $\left(2^{\text {nd }}-4^{\text {th }} / 8^{\text {th }}-10^{\text {th }}\right.$ Centuries $)$. London: Routledge.

Hamilton, J., and B. Hamilton, eds and trans. 1998. Christian Dualist Heresies in the Byzantine World c. 650-1450. Manchester: Manchester University Press.

Ibn al-Bit rīq, Sa'id (Eutychius). 1905. Annales, Kitāb al-Majmū' 'alā al-taḥqīq wa-al-tasộ īq. Edited by L. Cheikho [Corpus Scriptorum Christianourm Orientalium, Scriptores Arabici Textus. Ser. III, vol. 4]. Beirut: Matbạ 'at al-Abā' al-Yasū iyyīn.

Ibn 'Adī, Yahyāe. 1987. Jawāb Yahyā b. 'Adī 'an radd Abī 'Īsā al-Warrāq 'alā al-Nasậ rā, fī alittihāâ, in Abū 'Īsā al-Warrāq Yahyā b. 'Adī de l'Incarnation. Edited by E. Platti [Corpus Scriptorum Christianorum Orientalium 490, Scriptores Arabici 46]. Louvain: Peeters.

Ibn al-Nadīm, Abū al-Faraj. 1996. Kitāb al-fihrist. Edited by Y. Ṭaw̄il. Beirut: Dār al-Kutub al'Ilmiyya.

Ibn Ḥ azm, al-Andalusī. n.d. Kitāb al-fasl f̣̣ ī al-milal, wa-al-ahwā' wa-al-nihal. 5 vols. Beirut: Maktabat Khayyāṭ.

Ibn Qunstant ̣̣ n, Mạ̣būb (Agapius). 1911. Kitāb al- unwān: Histoire Universelle. Edited and translated by A. Vasiliev. [Patrologia Orientalis, 7, 4, part two]. Paris: Firmin Didot.

Jāḥiz, Aḅ ū 'Uthmān al-. 1991. Al-Radd 'alā al-Nasạ̄ rā. In Rasā' il al-Jāḥiz. Vol. 3. Edited bỵ A. Hārūn. Beirut: Dār al-J̄̄l.

Kaatz, K. 2012. Early Controversies and the Growth of Christianity. Santa Barbara, CA: Prager.

Khalidi, T. 2001. The Muslim Jesus: Sayings and Stories in Islamic Literature. Cambridge, MA: Harvard University Press.

Khalidi, T. 2003. Al-Injīl bi-riwāyat al-Muslimīn. Beirut: Dār al-Nahār li-al-Nashr.

Khawārizmī, Abū 'Abdallāh al-. n.d. Mafātīḥ al-'ulūm. Edited by A. M. al-'Abd. Cairo: Dār alNahḍa al-'Arabiyya.

Le Coz, R. 1992. Jean Damascène: Écrits sur Islam [Source Chrétiens 383]. Paris: Cerf.

Lemerle, P. 1973. "L'Histoire des Pauliciens d'Asie Mineure d'après le Sources Grecques." Travaux et Mémoires 5: 1-144.

Loos, M. 1974. Dualist Heresy in the Middle Ages. Prague: Academia Publishing House of the Czechoslovak Academy of Sciences.

Ludwig, C. 1998. "The Paulicians and Ninth-Century Byzantine Thought.” In Byzantium in the Ninth Century: Dead or Alive? Papers from the Thirtieth Symposium of Byzantine Studies. Birmingham, March 1996, edited by L. Brubaker, 23-36. Aldershot: Ashgate.

Maqdisī, al-Mutahhar, al-. n.d. Al-bad' wa-al-ta rīkh. Edited by C. Huart. 6 vols. Beirut: Dār Șādir.

Mas'ūdi, Abū al-Ḥ asan al-. 1894. Kitāb al-tanbīh wa-al-ishrāf. Edited by M. J. de Goeje. [Bibliotheca Geographorum Arabicorum 8]. Leiden: Brill.

Mas 'ūdī, Abū al-Ḥ asan al-. 1965. Murūj al-dhahab wa-ma'ādin al-jawhar. Vol. 5. Edited by Ch. Pellat. Beirut: Manshūrāt al-Jāmi a al-Lubnāniyya.

Monnot, G. 1983. “Les doctrines des chrètiens dans le 'Moghni’ de 'Abd al-Jabbar.” Mélanges de l'Institut Dominicain d'Etudes Orientales 16: 9-30.

Nāshi', al-Akbar al-. 1971. "Kitāb al-awsat.” In Werke des Naši' al-Akbar, edited by J. van Ess, 82-83. Beirut: Franz Steiner.

Nersoyan, T. 1996. The Armenian Church Historical Studies: Matters of Doctrine and Administration. New York: St Vartan Press.

O’Grady, J. 1995. Early Christian Heresies. New York: Barnes \& Noble. 
Papandrea, J. 2016. The Earliest Christologies: Five Images of Christ in the Postapostolic Age. Downer Grove, IL: Inter Varsity Press.

Penn, M. P. 2015. Envisioning Islam: Syriac Christians and the Early Muslim World. Philadelphia: University of Pennsylvania Press.

Qudāma, ibn Ja far. 1967. Kitāb al-kharāj. Edited by M. J. de Goeje. [Bibliotheca Geographorum Arabicorum 6]. Leiden: Brill.

Rassī, Ibn Ibrāhīm al-. 2000. Al-radd 'alā al-Nasạa rā. Edited by Imām Ḥ anafī 'Abdallah. Cairo: Dār al-Āfāq al- 'Arabiyya.

Räisänen, H. 1980. “The Portrait of Jesus in the Qur'an: Reflections of a Biblical Scholar.” The Muslim World 70 (2): 122-133.

Reeves, J. 2010. Prolegomena to a History of Islamicate Manichaeism. Sheffield: Equinox.

Reynolds, G. S. 2004. A Muslim Theologian in the Sectarian Milieu: 'Abd al-Jabbār and the Critique of Christian Origins. Leiden: Brill.

Reynolds, G. S. 2009. “The Muslim Jesus: Dead or Alive?” Bulletin of the School of Oriental and African Studies 72 (2): 237-258.

Reynolds, G. S. 2014. "On the Presentation of Christianity in the Qur'ān and Many Aspects of Qur'ānic Rhetoric.” Al-Bayān 12: 42-54.

Runciman, S. 1999. The Medieval Manichee: A Study of the Christian Dualist Heresy. Cambridge: Cambridge University Press.

Sahas, D. J. 1972. John of Damascus on Islam: The 'Heresy of the Ishmaelites'. Leiden: Brill.

Shahrastān̄̄, Abū al-Fatḥ al-. 1992. Kitāb al-milal wa al-niḥal. Edited by A. Muhammad. 2 vols. Beirut: Dār al-Kutub al-'Ilmiyya.

Simeon of Beth Arsham. 2002. Epistola de Barsauma. Edited and translated by S. S. Assemani. Repr. Piscataway, NJ: Gorgias Press.

Swanson, M. 2006. "Folly to the Hunafā": The Crucifixion in Early Christian-Muslim Controversy." In The Encounter of Eastern Christianity with Early Islam, edited by E. Grypeou, M. Swanson, and D. Thomas, 248-256. Leiden: Brill.

Tardieu, M. 1986. "Sabiens Coraniques et Sabiens de Harran.” Journal Asiatique 274: 1-44.

Thomas, D. 1996. "Abū 'Īsā al-Warrāq and the History of Religions." Journal of Semitic Studies, 41 (2): 275-290.

Thomas, D. 2002. Early Muslim Polemic Against Christianity: Abū 'Īsā al-Warrāq's Against the Incarnation. Cambridge: Cambridge University Press.

Thomas, D. 2006. "Christian Theologians and New Questions." In The Encounter of Eastern Christianity with Early Islam, edited by E. Grypeou, M. Swanson, and D. Thomas, 259-267.

Leiden: Brill.

Thurlkill, M. 2007. Chosen among Women: Mary and Fatima in Medieval Christianity and Sh'ite Islam. Notre Dame, IN: University of Notre Dame Press.

Tobias, Norman. 2007. Basil I Founder of the Macedonian Dynasty: A Study of the Political and Military History of the Byzantine Empire in the Ninth Century. Lewiston, NY: Edwin Mellen Press.

Tolan, J. 2002. Saracens: Islam in the Medieval European Imagination. New York: Columbia University Press.

T abarī, Abū Jarīr al-. 1960. Ta' rīkh al-rusul wa-al-mulūk. Edited by M. Abū al-Faḍl Ibrāhīm. 11 vols. Cairo: Dār al-Ma'ārif.

Vasiliev, A. 1935. Byzance et les arabes: La dynastie d'Amorium (820-867). Vol. 1. [Corpus Bruxellense Historiae Byzantinae 1]. Brussels: Institute de Philologie et d'Histoire Orientales.

Warrāq, Abū 'Isā al-. 1992. Anti-Christian Polemic in Early Islam: Abū 'Īsā al-Warrāq's Against the

Trinity. Edited and translated by David Thomas. Cambridge: Cambridge University Press. 
Warrāq, Abū 'Īsā al-. 2002. Early Muslim Polemic against Christianity: Abū 'Īsā al-Warrāq's Against the Incarnation. Edited and translated by David Thomas. Cambridge: Cambridge University

Press.

Wensinck, A. J. 1991. “art. Maryam.” In Encyclopedia of Islam, Vol. 6, 628-632. Leiden: Brill.

Zaman, M. Q. 1997. Religion and Politics under the Early 'Abbasids: The Emergence of the ProtoSunni Elite. Leiden: Brill.

Post-print standardized by MSL Academic Endeavors, the imprint of the Michael Schwartz Library at Cleveland State University, 2016 